\title{
ERN1 DEPENDENT REGULATION OF TMED10, MYL9, SPOCK1, CUL4A AND CUL4B GENES EXPRESSION AT GLUCOSE AND GLUTAMINE DEPRIVATIONS IN U87 GLIOMA CELLS
}

\author{
O. H. MINCHENKO ${ }^{凶}$, O. S. HNATIUK, D. O. TSYMBAL, \\ Y. M. VILETSKA, S. V. DANILOVSKYI, O. V. HALKIN, \\ I. V. KRYVDIUK, O. V. RUDNYTSKA
}

Palladin Institute of Biochemistry, National Academy of Sciences of Ukraine, Kyiv; 凶e-mail: ominchenko@yahoo.com

Received: 05 April 2020; Accepted: 25 June 2020

\begin{abstract}
It was shown previously that inhibition of ERN1 (endoplasmic reticulum to nucleus signaling 1) pathway, a central mediator of the unfolded protein response, leads to suppression of tumor growth through downregulation of key pro-proliferative and up-regulation of tumor suppressor factors and modifies the sensitivity of these genes to glucose and glutamine deprivation. However, the executive mechanisms of ERN1 mediated control of glioma cell proliferation are not yet known. The goal of this study was to estimate the effect of glucose and glutamine deprivations on expression of cancer related genes in glioma U87 cells at ERN1 signaling inhibition for evaluation of their possible significance in ERN1 mediated control of glioma cell proliferation. We studied the effect of glucose and glutamine deprivations on the expression level of cancer related genes encoding TMED10 (transmembrane p24 trafficking protein 10), MYL9 (myosin, light chain 9, regulatory), SPOCK1 (sparc/osteonectin, cwcV and kazal-like domains proteoglycan 1), CUL4A (cullin 4A), and CUL4B in U87 glioma control cells and cells with ERN1 knockdown. It was shown that at glucose deprivation, the expression level of MYL9, SPOCK1 and CUL4B genes was significantly up-regulated in control glioma cells. ERN1 knockdown modified the sensitivity to glucose deprivation of all studied genes except TMEDIO gene. At glutamine deprivation, the expression of MYL9, CUL4A and CUL4B genes was shown to be up-regulated in control glioma cells. The sensitivity of MYL9, TMED10 and CUL4B gene expression to glutamine deprivation in glioma cells with ERN1 knockdown was significantly modified, while CUL4A and SPOCK1 gene expression did not respond to ERN1 inhibition. The present study demonstrates that glucose and glutamine deprivation affected the expression of the most studied genes in a specific manner and that inhibition of ERN1 signaling preferentially modified their expression at glucose and glutamine deprivation.
\end{abstract}

K e y w o r d s: mRNA expression, TMED10, MYL9, SPOCK1, CUL4A, CUL4B, CUL4B, ERN1 inhibition, glucose and glutamine deprivation, U87 glioma cells.

$\mathrm{M}$ alignant gliomas are highly aggressive tumors and characterized by extensive tumor cell invasion into the normal brain parenchyma. It is well known that gliomas growth strongly depends on endoplasmic reticulum stress, glutamine and glucose levels as well as hypoxia, which are obligate components of tumor progression [1-6]. Previously was shown that blockade of ERN1 (endoplasmic reticulum to nucleus signaling 1) signaling pathway of the endoplasmic reticulum stress leads to suppression of cell proliferation and tumor growth through changing in the expression level of genes, which responsible for control of glycolysis, cell cycle, apoptosis, angiogenesis and many other processes to enhance tumor cells proliferation under stressful environmental conditions [7-11]. Cell proliferation is strongly dependent under glycolysis and glucose level because there is the molecular connection between cell cycle progression and the provision of nutrients essential for this purpose. Glucose

(C) 2020 Minchenko O. H. et al. This is an open-access article distributed under the terms of the Creative Commons Attribution License, which permits unrestricted use, distribution, and reproduction in any medium, provided the original author and source are credited. 
as well as glutamine are important substrates for glycolysis and glutaminolysis, which are important to glioma development and a more aggressive behavior through regulation of the cell cycle at distinct stages [12-14]. Furthermore, a better knowledge of tumor responses to glucose and glutamine deprivation conditions is required to elaborate therapeutical strategies of cell sensibilization, based on the blockade of survival mechanisms [15-18].

For this study we select five cancer related genes encoding TMED10 (transmembrane p24 trafficking protein 10), MYL9 (myosin, light chain 9, regulatory), SPOCK1 (sparc/osteonectin, $\mathrm{cwcv}$ and kazal-like domains proteoglycan 1), CUL4A (cullin 4A), and CUL4B polyfunctional proteins. TMED10 is a member of a heteromeric secretase complex and involved in vesicular trafficking of various proteins including $\mathrm{G}$ protein-coupled receptors. Its expression is associated with cancers and correlated to THOC5 expression level in primary hepatocellular carcinomas [19]. Therefore, there is data that TMED10 modulates growth of papillary thyroid cancer cells by inducing autophagy, which may be associated with activation of AMPK/mTOR pathway [20]. Recently was shown that the expression of myosin light chain 9 (MYL9) is very important for growth of glioblastoma and other malignant tumors [21, 22]. Thus, the association of high MYL9 expression with poor prognosis in newly diagnosed glioblastoma patients and increased expression in recurrent glioblastoma is indicative of its role in conferring tumour aggressiveness [21]. At the same time, there is data that decreased expression of myosin light chain MYL9 may play an important role in malignant tumor progression of prostate cancer [23].

SPOCK1 may play a role in cell-cell and cellmatrix interactions. It plays an important role in cancerogenesis because there is data that overexpression of this gene contributes to the aggressive nature of head and neck squamous cell carcinoma and that reduced SPOCK1 expression inhibits cancer cell proliferation as well as migration through Wnt/betacatenin signaling and other mechanisms [24-26]. Cullins (CUL4A and CUL4B) are the core component of multiple cullin-RING-based E3 ubiquitinprotein ligase complexes which mediate the ubiquitination and subsequent proteasomal degradation of target proteins and involved in tumorigenesis [27-31]. Thus, these cullins play a role in PCNA-dependent polyubiquitination of CDT1 and MDM2-dependent ubiquitination of TP53 as well as in the mammalian target-of-rapamycin (mTOR) pathway involved in control of cell growth, size and metabolism. There is also data that circular RNA ZFR exhibited a carcinogenic role by sponging miR-101-3p and regulating CUL4B expression in non-small cell lung cancer and that overexpression of miR-494 inhibited proliferation, migration, invasion and EMT of ovarian cancer cells by directly suppressing CUL4A expression $[28,30]$. It was also shown that decreased CUL4B expression inhibits malignant proliferation of glioma in vitro and in vivo [32]. It is interesting to note that CUL4B upregulates the expression of C-MYC at post-transcriptional level through epigenetic silencing of miR-33b-5p and that CUL4B/miR-33b/CMYC axis promotes prostate cancer progression [33].

Previously was shown that the inhibition of ERN1, a central mediator of the unfolded protein response, leads to suppression of tumor growth through down-regulation of key pro-proliferative and up-regulation of tumor suppressor factors and modifies the sensitivity of these genes to glucose and glutamine deprivation [34-40]. However, the executive mechanisms of the exhibited anti-proliferative effects of ERN1 inhibition are not yet known. It is possible that this anti-proliferative effect is also mediated by altered expression of TMED10, MYL9, SPOCK1, CUL4A, and CUL4B genes, which are integrated into the unfolded protein response signaling pathways and regulate cell proliferation.

The main goal of this study was investigation the effect of glucose and glutamine deprivations on the expression of cancer related genes (TMED10, MYL9, SPOCK1, CUL4A, and CUL4B) in glioma U87 cells in relation to inhibition of ERN1 signaling for evaluation of their possible significance in ERN1 signaling mediated control of glioma cell proliferation.

\section{Materials and Methods}

Cell lines and culture conditions. The glioma cell line U87 (HTB-14) was obtained from ATCC (USA) and grown in high glucose (4.5 g/l) Dulbecco's modified Eagle's minimum essential medium (DMEM; Gibco, Invitrogen, U.S.A.) supplemented with fetal bovine serum (Equitech-Bio, Inc., USA), glutamine $(2 \mathrm{mM}), 10 \%$ penicillin (100 units $/ \mathrm{ml}$; Gibco, USA) and streptomycin ( $0.1 \mathrm{mg} / \mathrm{ml}$; Gibco) at $37^{\circ} \mathrm{C}$ in a $5 \% \mathrm{CO}_{2}$ incubator. Glucose and glutamine deprivation conditions were created by changing the complete DMEM medium into culture plates on the medium without glucose or glutamine and plates were exposed to this condition for $16 \mathrm{~h}$. 
In this study we used two sublines of U87 glioma cells. One subline was obtained by selection of stable transfected clones with overexpression of vector pcDNA3.1, which was used for creation of dominant/negative ERN1 (dnERN1). This untreated subline of glioma cells we used as a control (control glioma cells) in the study of the effect of glutamine and glucose deprivations on the expression level of TMED10, MYL9, SPOCK1, CUL4A, and CUL4B genes. Second subline was obtained by selection of stable transfected clone with overexpression of ERN1 dominant/negative construct (dnERN1) and consequent inhibition of both protein kinase and endoribonuclease activities of this signaling protein of endoplasmic reticulum stress [7]. It has been shown that these cells have a low proliferation rate and do not express spliced XBP1, a key transcription factor in ERN1 signaling, after induction of endoplasmic reticulum stress by tunicamycin $[7,8]$. The expression of the studied genes was compared with cells transfected with the empty vector (control glioma cells, pcDNA3.1). The efficiency of ERN1 suppression in this glioma cell subline was estimated previously $[7,8]$ by determining the expression level of spliced XBP1, a key transcription factor in the ERN1 signaling, and the level of the phosphorylated ERN1 isoform in cells treated by tunicamycin $(0.01 \mathrm{mg} / \mathrm{ml}$ during $2 \mathrm{~h})$. Both sublines of glioma cells used in this study were grown with geneticin (G418) while these cells carry an empty pcDNA3.1 vector or dnERN1construct.

RNA isolation. Total RNA was extracted from glioma cells using Trizol reagent according to manufacturer protocol (Invitrogen, U.S.A.) as described previously $[8,41]$. The RNA pellets were washed with $75 \%$ ethanol and dissolved in nuclease-free water. For additional purification, RNA samples were re-precipitated with $95 \%$ ethanol and re-dissolved again in nuclease-free water. RNA concentration and spectral characteristics were measured using NanoDrop Spectrophotometer ND1000 (PEQLAB, Biotechnologie $\mathrm{GmbH}$ ).

Reverse transcription and quantitative PCR analysis. Thermo Scientific Verso cDNA Synthesis Kit (Germany) was used for cDNA synthesis according to manufacturer protocol. The expression levels of TMED10, MYL9, SPOCK1, CUL4A, and CUL4B mRNAs as well as ACTB mRNA were measured in U87 glioma cells by real-time quantitative polymerase chain reaction using "QuantStudio 5 Real-Time PCR System” (Applied Biosystems, USA) and Absolute qPCR SYBRGreen Mix (Thermo Fisher Scientific, ABgene House, UK). Polymerase chain reaction was performed in triplicate using specific pair of primers, which were received from Sigma-Aldrich, USA.

For amplification of TMED10 (transmembrane p24 trafficking protein 10), which also known as TMP21 (21 kDa transmembrane trafficking protein), cDNA we used forward (5'-CATGGGGTACCACCTACACC $-3^{\prime}$ and reverse (5'-AACCCAGGACAAATGCTGAC- $3^{\prime}$ ) primers. The nucleotide sequences of these primers correspond to sequences 874-893 and 1032-1013 of human TMED10 cDNA (GenBank accession number NM_006827). The size of amplified fragment is $159 \mathrm{bp}$. The amplification of SPOCK1 (sparc/osteonectin, cwcv and kazal-like domains proteoglycan 1) cDNA for real time RCR analysis was performed using two oligonucleotides primers: forward - 5'-GGCCTTCATACCTCGGTGTA- $3^{\prime}$ and reverse $-5^{\prime}-$ CTTTGTCCTTTGGTCCCAGC -3 '. The nucleotide sequences of these primers correspond to sequences 1144-1163 and 1379-11360 of human SPOCK1 cDNA (GenBank accession number NM_004598). The size of amplified fragment is $236 \mathrm{bp}$. For amplification of MYL9 (myosin, light chain 9, regulatory), which also known as MYRL2 (myosin regulatory light chain 2), we were used forward (5'-ACCAGAAGCCAAGATGTCCA-3' and reverse (5'-CAGGTATTCGTCTGTGGGGT-3') primers. The nucleotide sequences of these primers correspond to sequences 57-76 and 279-260 of human MYL9 cDNA (GenBank accession number NM_006097). The size of amplified fragment is 223 bp. The amplification of CUL4A (cullin 4A) cDNA for real time RCR analysis was performed using two oligonucleotides primers: forward - 5'-CTACTGGCCAACATACACGC- $3^{\prime}$ and reverse (5'-AAGCCATCTCCCTCGTTGAA-3'). The nucleotide sequences of these primers correspond to sequences 1542-1561 and 1772-1753 cDNA of human CULL4A (GenBank accession number NM_003589). The size of amplified fragment is $231 \mathrm{bp}$. For amplification of CUL4B (cullin 4B) cDNA we used forward (5'AGCCCTGCAGTCTATCATCC $-3^{\prime}$ and reverse (5'ACATCATCCGTCCTTTGGGT- $3^{\prime}$ ) primers. The nucleotide sequences of these primers correspond to sequences 241-260 and 444-425 of human CUL4B cDNA (GenBank accession number NM_003588). The size of amplified fragment is $204 \mathrm{bp}$. The amplification of beta-actin (ACTB) cDNA was performed using forward - 5'-GGACTTCGAGCAAGAGA- 
TGG-3' and reverse - 5'-AGCACTGTGTTGGCGTACAG-3' primers. These primer nucleotide sequences correspond to 747-766 and 980-961 of human ACTB cDNA (NM_001101). The size of amplified fragment is $234 \mathrm{bp}$. The expression of betaactin mRNA was used as control of analyzed RNA quantity. The primers were received from SigmaAldrich (St. Louis, MO, USA).

Quantitative PCR analysis was performed using "Differential expression calculator" software. The values of TMED10, MYL9, SPOCK1, CUL4A, and $C U L 4 B$ gene expressions were normalized to the expression of $\beta$-actin mRNA and represented as percent of control (100\%). All values are expressed as mean \pm SEM from triplicate measurements performed in 4 independent experiments. The amplified DNA fragments were also analyzed on a $2 \%$ agarose gel and visualized by SYBR* Safe DNA Gel Stain (Life Technologies, Carlsbad, CA, USA).

Statistical analysis. Statistical analysis was performed according to Student's $t$-test using Excel program as described previously [42, 43]. All values are expressed as mean \pm SEM from triplicate measurements performed in 4 independent experiments.

\section{Results and Discussion}

To determine if glucose and glutamine deprivations affect the expression level of genes encoding TMED10 (transmembrane p24 trafficking protein 10), SPOCK1 (sparc/osteonectin, cwcv and kazal-like domains proteoglycan 1), MYL9 (myosin, light chain 9, regulatory), CUL4A (cullin 4A) and CUL4B, which play multifunctional role in tumorigenesis, through the ERN1 branch of endoplasmic reticulum stress response, we investigated the effect of glucose and glutamine deprivations on the expression level of these genes in control glioma cells (transfected by vector) and cells without both enzymatic activities of this signaling protein.

As shown in Fig. 1, A, exposure of control glioma cells under glucose deprivation condition leads to significant up-regulation of the expression level of MYL9 mRNA ( $+55 \%)$ in control glioma cells as compared to control 1. To investigate a possible role of endoplasmic reticulum stress signaling mediated by ERN1 enzyme in regulation of the expression of MYL9 gene by glucose deprivation, we investigated the effect of glucose deprivation condition on this gene expression in glioma cells without enzy-
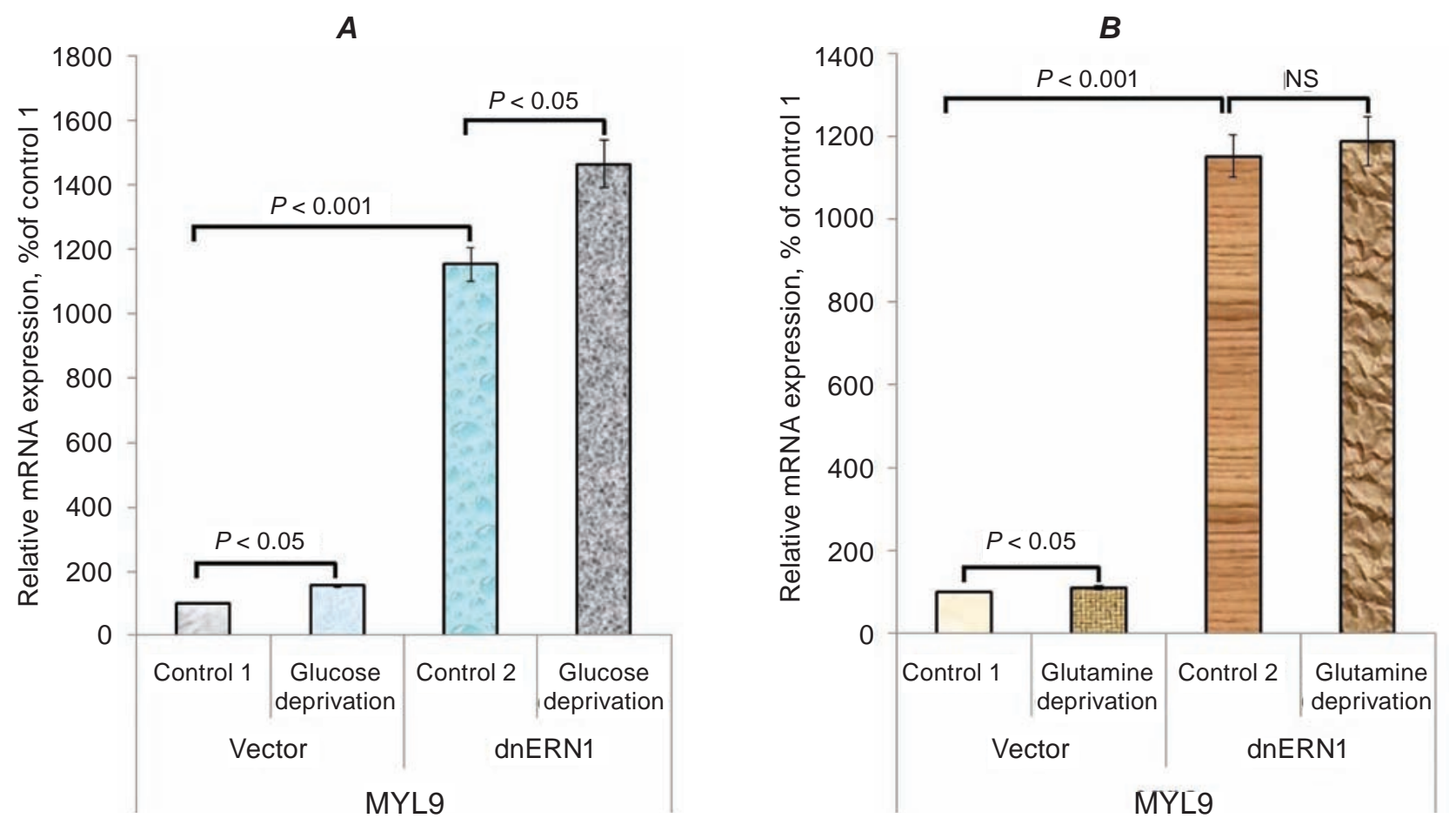

Fig. 1. Effect of glucose (A) and glutamine (B) deprivation on the expression level of MYL9 (myosin, light chain 9, regulatory) gene in control U87 glioma cells (Vector) and cells with ERN1 knockdown (dnERN1) measured by qPCR. The values of MYL9 mRNA expression were normalized to $\beta$-actin mRNA level and presented as percent of control (100\%); $n=4$ 
matic activities of ERN1 signaling protein. It was shown that inhibition of ERN1 signaling by dnERN1 significantly modifies effect of glucose deprivation on the expression level of MYL9 gene as compared to control glioma cells (Fig. 1, A). Thus, effect of glucose deprivation on the expression level of MYL9 gene in glioma cells with knockdown of ERN1 signaling protein is significantly lesser $(+27 \%$ versus control 2) in comparison to control glioma cells.

As shown in Fig. 1,B, exposure of control glioma cells under glutamine deprivation condition leads to small but statistically significant changes $(+13 \%)$ in the expression level of MYL9 mRNA as compared to control 1; however, inhibition of ERN1 signaling protein completely eliminates the sensitivity of this gene expression to glutamine deprivation. Therefore, inhibition of ERN1 modifies the sensitivity of MYL9 gene expression to glutamine deprivation condition in U87 glioma cells.

Investigation of TMED10 gene expression in control U87 glioma cells and cells with ERN1 knockdown shown that the expression of this gene is resistant to glucose deprivation condition independently from inhibition of ERN1 signaling by
dnERN1 (Fig. 2, A). Glutamine deprivation condition also did not changed the expression levels of TMED10 mRNA in control U87 glioma cells, but inhibition of the signaling protein ERN1 by dnERN1 down-regulated this gene expression level $(-32 \%$ as compared to control 2; Fig. 2, B).

As shown in Fig. 3, A, glucose deprivation condition is significantly up-regulated $(+52 \%)$ the expression level of SPOCK1 mRNA in control glioma cells as compared to control 1. However, inhibition of ERN1 signaling eliminates the sensitivity of this gene expression to glucose deprivation condition. Therefore, the expression level of SPOCK1 mRNA is resistant to glutamine deprivation condition in both control and ERN1 knockdown glioma cells (Fig. 3, B).

We also investigated the expression of cullin 4A gene upon glucose and glutamine deprivation condition in both control glioma cells and cells without ERN1 signaling enzyme function. As shown in Fig. 4,A, exposure of control glioma cells under glucose deprivation condition did not change significantly the expression of CUL4A gene in control glioma cells. At the same time, ERN1 inhibition leads to
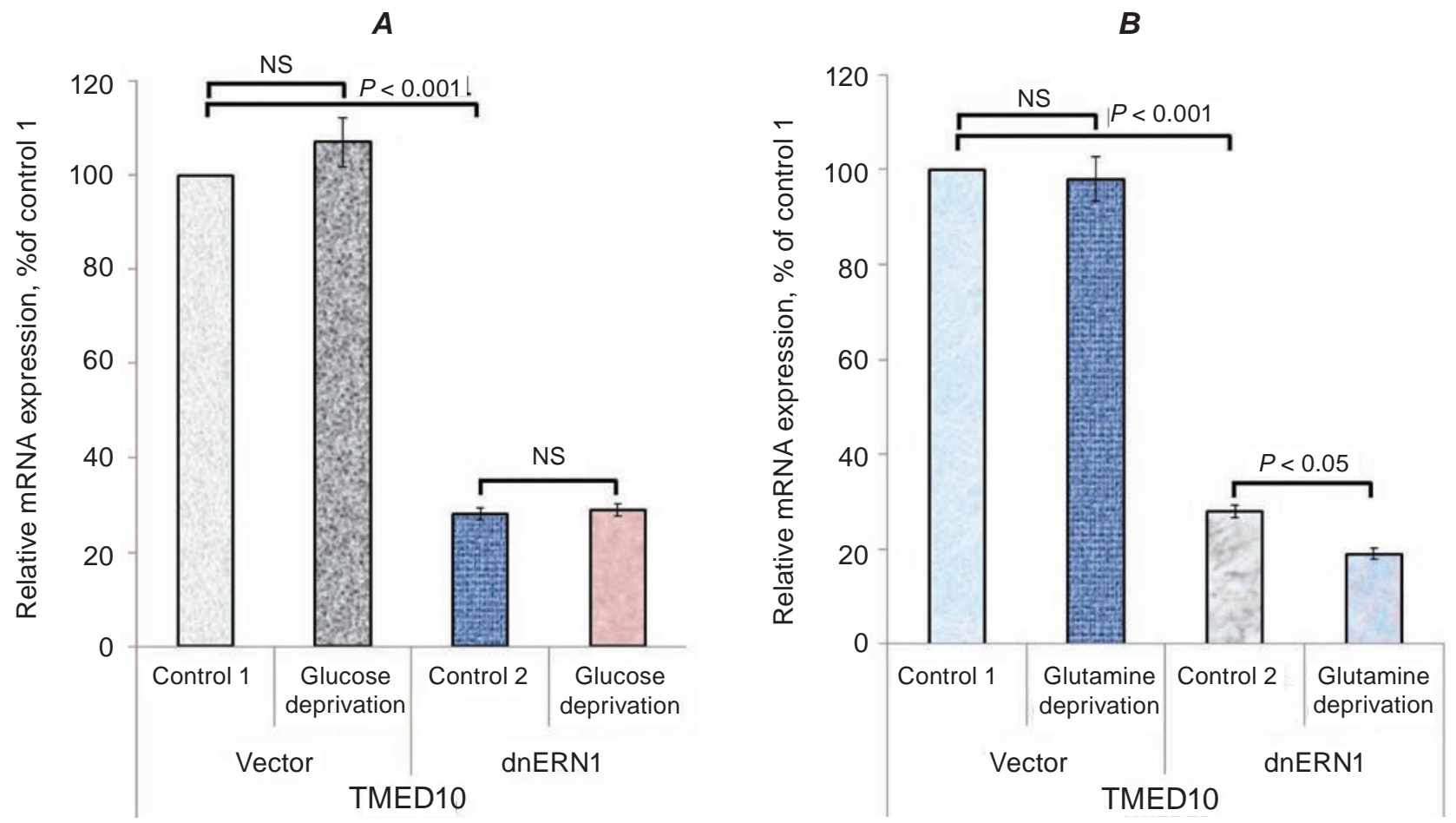

Fig. 2. Effect of glucose (A) and glutamine (B) deprivations on the expression level of TMED10 (transmembrane p24 trafficking protein 10) gene in control U87 glioma cells (Vector) and cells with ERN1 knockdown (dnERN1) measured by qPCR. The values of TMED10 mRNA expression were normalized to $\beta$-actin mRNA level and presented as percent of control (100\%); $n=4$ 
A

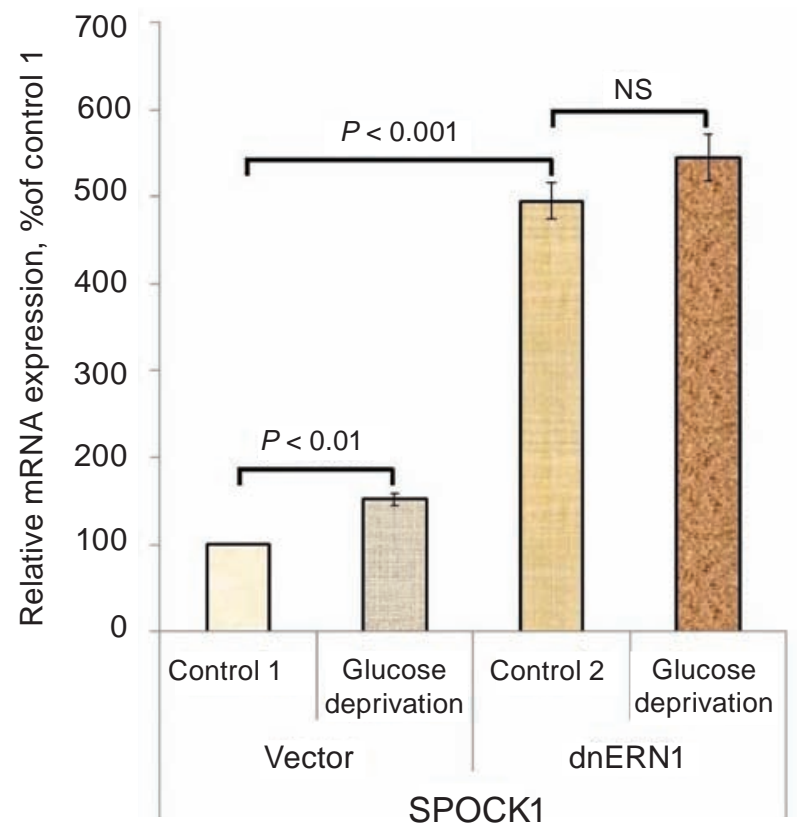

B

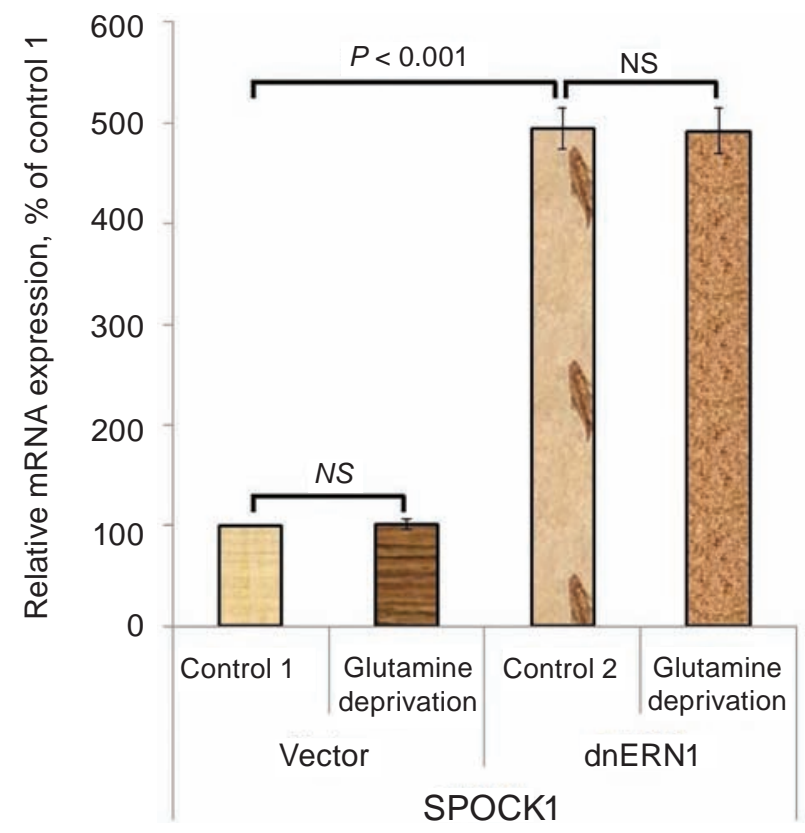

Fig. 3. Effect of glucose (A) and glutamine (B) deprivation on the expression level of SPOCK1 (sparc/osteonectin, cwcv and kazal-like domains proteoglycan 1) gene in control U87 glioma cells (Vector) and cells with ERN1 knockdown (dnERN1) measured by qPCR. The values of SPOCK1 mRNA expression were normalized to $\beta$-actin $m R N A$ level and presented as percent of control (100\%); $n=4$

A

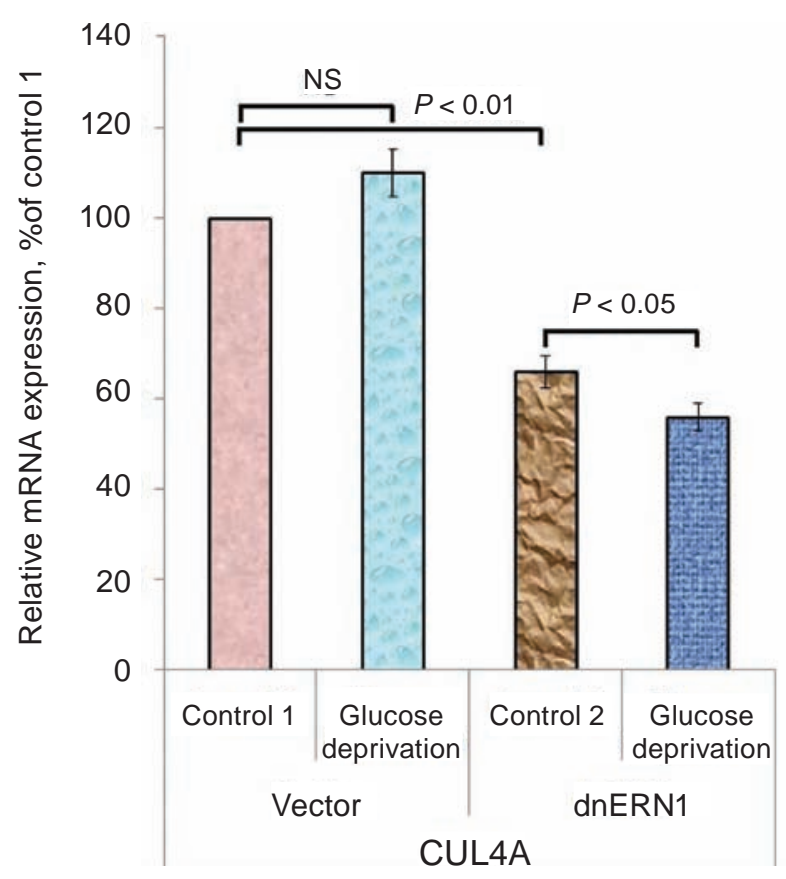

$B$

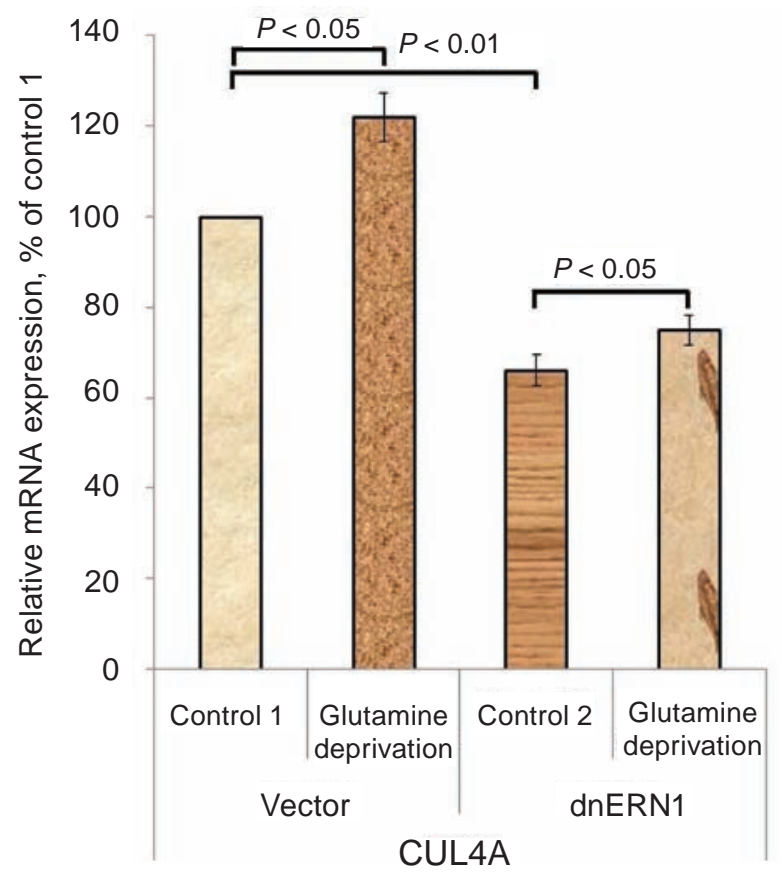

Fig. 4. Effect of glucose (A) and glutamine (B) deprivation on the expression level of CUL4A (cullin 4A) gene in control U87 glioma cells (Vector) and cells with ERN1 knockdown (dnERN1) measured by qPCR. The values of CULAA mRNA expression were normalized to $\beta$-actin $m R N A$ level and presented as percent of control (100\%); $n=4$ 
$A$

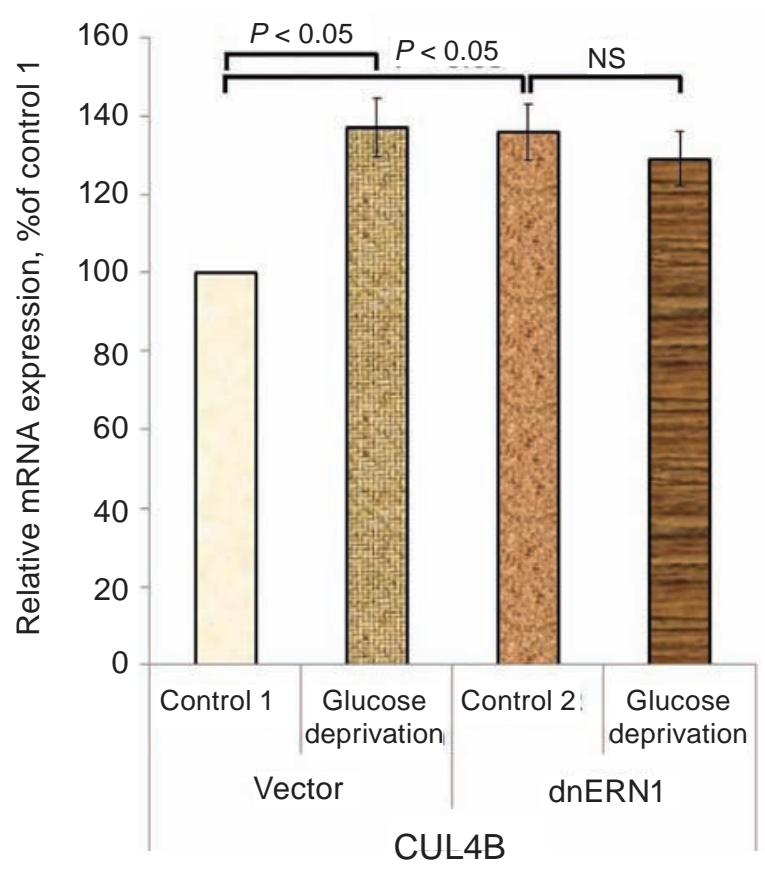

$B$

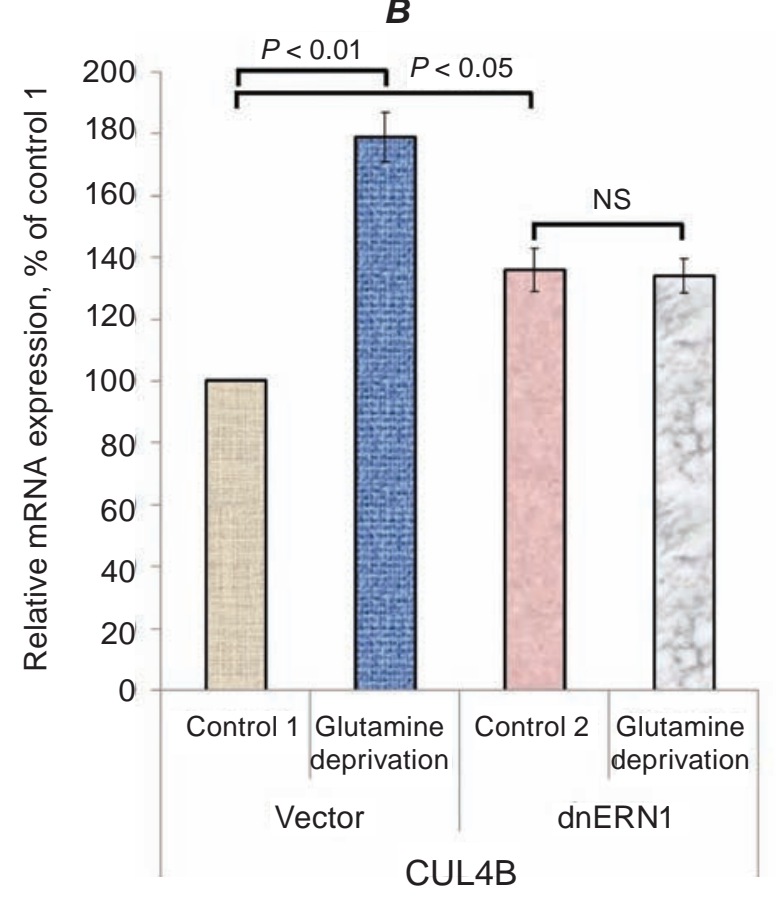

Fig. 5. Effect of glucose (A) and glutamine (B) deprivation on the expression level of CUL4B (cullin $4 B$ ) gene in control U87 glioma cells (Vector) and cells with ERN1 knockdown (dnERN1) measured by qPCR. The values of CULAB $m R N A$ expression were normalized to $\beta$-actin mRNA level and presented as percent of control (100\%); $n=4$

small but statistically significant down-regulation of this gene expression (-15\%) as compared to control 2 (Fig. 4, A). Glutamine deprivation condition causes up-regulation of the expression levels of CUL4A mRNA in both control and ERN1 knockdown U87 glioma cells: $+22 \%$ and $+14 \%$, correspondingly (Fig. 4, B).

Next we investigated the effect of glucose and glutamine deprivation conditions on the expression level of CUL4B mRNA in relation to ERN1 inhibition. Results of this investigation are presented in Fig. 5.

In control glioma cells the expression level of CUL4B gene is increased $(+37 \%)$ under glucose deprivation condition (Fig. 5, A). At the same time, inhibition of ERN1 by dnERN1 introduces the resistance of CUL4B gene expression to glucose deprivation in U87 glioma cells (Fig. 5, A). Similar results were obtained with glutamine deprivation condition: up-regulation of CUL4B gene expression $(+79 \%)$ in control glioma cells and elimination the sensitivity of this gene expression to glutamine deprivation condition in glioma cells with ERN1 knockdown (Fig. 5, B).
Therefore, the exposure of control glioma cells under glucose and glutamine deprivation conditions leads to up-regulation of most studied genes expression in gene specific manner, but inhibition of ERN1 signaling preferentially modified sensitivity of their expression to these experimental conditions. Summarized results of the investigation of expression profile of genes encoding TMED10, MYL9, SPOCK1, CUL4A, and CUL4B regulatory proteins in the control and ERN1 knockdown glioma cells under glucose and glutamine deprivation conditions are presented in Fig. 6 .

In this work we studied the effect of glucose and glutamine deprivation conditions on the expression of a cancer related genes encoding functionally different proteins (TMED10, MYL9, SPOCK1, CUL4A, and CUL4B) in control U87 glioma cells and cells with ERN1 knockdown for evaluation of possible significance of these genes in the control of glioma growth through endoplasmic reticulum stress signaling mediated by ERN1 and nutrient deprivation. Investigation of the expression of TMED10, MYL9, SPOCK1, CUL4A, and CUL4B genes in glioma cells under glucose and glutamine deprivation 

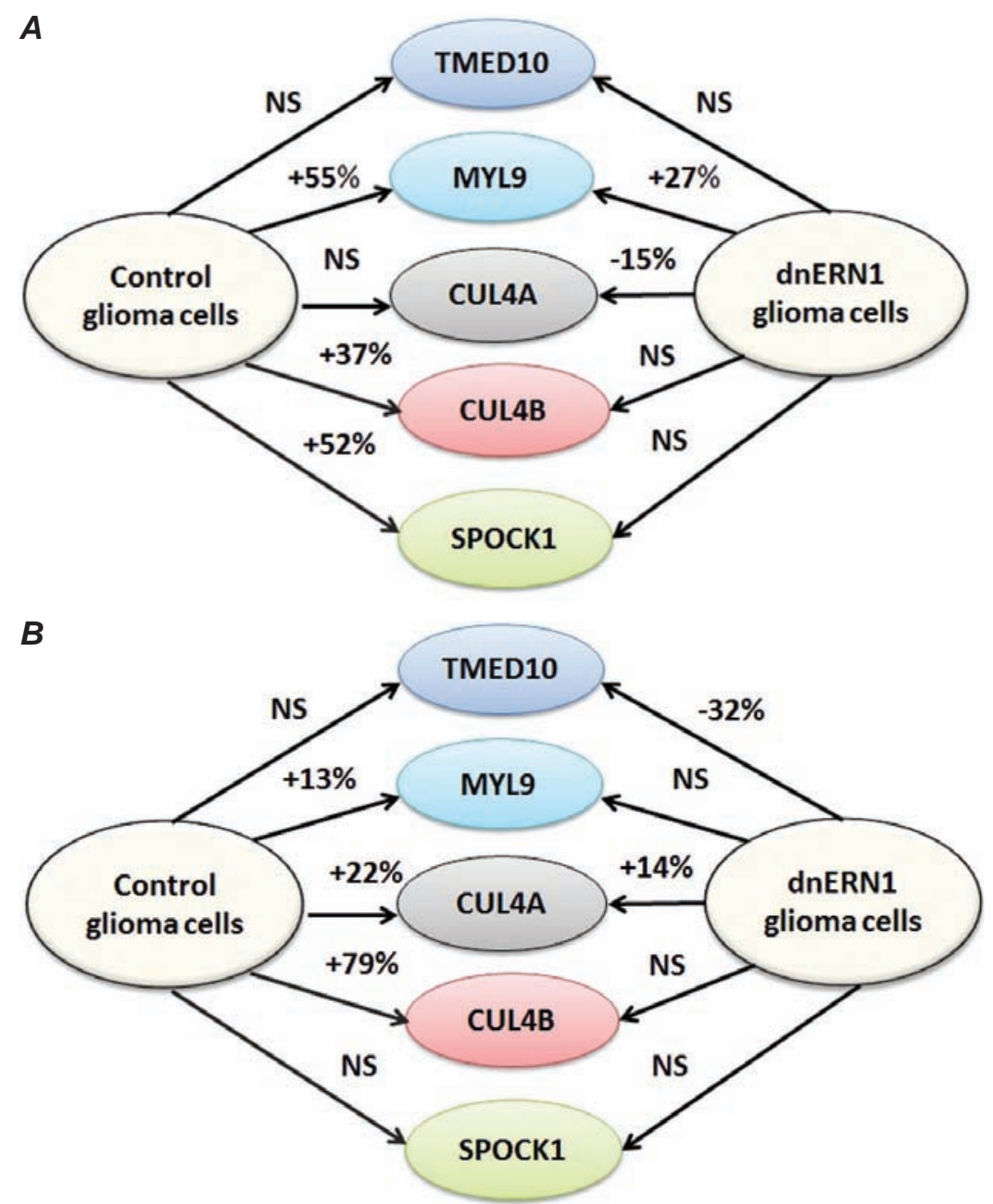

Fig. 6. Schematic demonstration of changes in the expression profile of genes encoding TMED10, MYL9, SPOCK1, CUL4A, and CUL4B regulatory proteins in the control and ERN1 knockdown (dnERN1) glioma cells under glucose (A) and glutamine (B) deprivations; NS - no significant change

conditions in respect to inhibition of ERN1 signaling is important for understanding of malignant tumor growth mechanisms, because glucose and glutamine supply as well as endoplasmic reticulum stress play an essential role in the control of tumor progression $[1,3,5,12,18]$. The growing tumor requires the endoplasmic reticulum stress and hypoxia for apoptosis inhibition, neovascularization and growth $[5,38,40]$. Cell proliferation is strongly dependent on glutamine and glucose supply as well as glycolysis because there is the molecular connection between cell cycle progression and the provision of substrates essential for this purpose $[5,13,16,17]$.

In this study we demonstrated that the expression of most studied genes in control glioma cells is affected by glucose and glutamine deprivation conditions as compared to cells growing upon normal condition (with complete DMEM; Fig. 6). At the same time, the expression level of TMED10 gene is resistant to both glucose and glutamine deprivation conditions in control glioma cells, but inhibition of ERN1 and consequent cell proliferation introduces down-regulation of this gene expression in cells treated by glutamine deprivation. These results agree well with prooncogenic function of TMED10 $[19,20]$. It is well known that MYL9 has pro-proliferative properties in glioblastoma and some other tumors [21-23]. Thus, our results concerning suppressive effect of ERN1 knockdown on the expression of MYL9 mRNA under glucose and glutamine deprivations also agree well with functional role of this protein. Similar results we have received with SPOCK1 gene expression in glioma cells treated by glucose deprivation: up-regulation in control cells and elimination of this effect in ERN1 knockdown cells (Fig. 6), which are mostly consistent with 
pro-cancerogenic role of SPOCK1 [24-26]. Protein CUL4B is the core component of multiple cullinRING-based E3 ubiquitin-protein ligase complexes and also involved in tumorigenesis through variable signaling pathways [27, 30-33]. Our results shown that glucose and glutamine deprivations lead to upregulation of CUL $4 B$ gene expression and that inhibition of ERN1 completely eliminates this effect of nutrient deprivation. Therefore, our results concerning suppressive effect of ERN1 knockdown on the sensitivity of CUL4B mRNA expression under both glucose and glutamine deprivations agree well with functional role of CUL4B protein.

It is interesting to note, that treatment of glioma cells by glucose and glutamine deprivations has different effect on the expression of TMED10, MYL9, SPOCK1, CUL4A, and CUL4B genes in gene specific manner. Moreover, inhibition of ERN1 signaling enzyme modifies the regulation of the expression of all studied genes by glucose and glutamine deprivations also in gene specific manner. It is possible that molecular mechanisms of regulation of different gene expressions are complex and depend on multiple factors. Our results support idea that regulation of different gene expressions by glucose and glutamine deprivations is upon complex network, which partially controlled by ERN1 signaling. It is known that suppression of ERN1 enzymatic activities in gliomas leads to the inhibition of tumor neovascularization together with the development of a more invasive phenotype [7]. It is reasonable to suggest, that combined impact of glucose and glutamine deprivations and ERN1 inhibition on the expression of key regulatory factors may contribute to the decreased proliferation potential of ERN1 knockdown glioma cells. Similar results were obtained previously for regulation of many other genes [16, 37-40].

Therefore, present study demonstrates that glucose and glutamine deprivations affect almost all studied genes expression and that inhibition of ERN1 can suppress up-regulation of most studied gene expressions in gene specific manner and thus possibly contributes to slower glioma growth. However, the detailed molecular mechanisms of ERN1-mediated regulation of the expression of TMED10, MYL9, SPOCK1, CUL4A, and CUL4B genes, which have a pivotal role in the control of malignant tumor growth, are complex and warrants further investigation.
Conflict of interest. Authors have completed the Unified Conflicts of Interest form at http://ukrbiochemjournal.org/wp-content/uploads/2018/12/ coi_disclosure.pdf and declare no conflict of interest.

Funding. This work was funded by the State Budget Program "Support for the Development of Priority Areas of Scientific Research" (Code: 6541230).

\section{ЗАЛЕЖНА ВIД ЕRN1 РЕГУЛЯЦІЯ ЕКСПРЕСІЇ ГЕНIВ TMED10, MYL9, SPOCK1, CUL4A I CUL4B B КЛІТИНАХ ГЛІОМИ ЛІНІЇ U87 ЗА ДЕФІЦИТУ ГЛУТАМІНУ ТА ГЛЮКОЗИ}
О. Г. Мінченко ${ }^{\bowtie}$, О. С. Гнатюк,
Д. О. Цимбал, Ю. М. Вілецька,
С. В. Даніловський, О. В. Галкін,
I. В. Кривдюк, О. В. Руднииька
Інститут біохімії ім. О. В. Палладіна НАН України, Київ;
e-mail: ominchenko@yahoo.com

Як було показано раніше, пригнічення ERN1 (endoplasmic reticulum to nucleus signaling 1) сигнального шляху призводить до уповільнення росту пухлини внаслідок зниження експресії основних про-проліферативних генів та посилення експресії супресорних генів, а також змінює чутливість цих генів до дефіциту глюкози та глутаміну. Однак, виконавчі механізми ERN1 опосередкованого контролю проліферації гліомних клітин залишаються нез'ясованими. Метою дослідження було оцінити вплив дефіциту глюкози та глутаміну на експресію генів, що контролюють пухлинний ріст у клітинах гліоми U87. Нами вивчено вплив дефіциту глюкози та глутаміну на рівень експресії залучених до контролю пухлинного росту генів, що кодують TMED10 (transmembrane p24 trafficking protein 10), MYL9 (myosin, light chain 9, regulatory), SPOCK1 (sparc/osteonectin, cwcv and kazal-like domains proteoglycan 1), CUL4A (cullin 4A) та CUL4B в клітинах гліоми лінії U87 у контролі та за нокдауну ERN1. Показано, що за дефіциту глюкози спостерігалось значне підвищення рівня експресії генів MYL9, SPOCK1 та 
$C U L 4 B$ в контрольних клітинах гліоми. Нокдаун ERN1 модифікував чутливість до дефіциту глюкози всіх досліджених генів за винятком гена TMED10. В умовах дефіциту глутаміну експресія генів MYL9, CUL4A та CUL4B в контрольних клітинах гліоми посилювалась. У клітинах гліоми з пригніченим ERN1 чутливість експресії генів MYL9, TMED10 та CUL4B до дефіциту глутаміну була істотно зміненою, тоді як експресія генів CUL4A та SPOCK1 не залежала від пригнічення ERN1. Результати роботи продемонстрували, що за дефіциту глюкози і глутаміну експресія більшості досліджених генів специфічно порушується і що пригнічення ERN1 сигналювання за таких умов модифікує їх експресію. Виявлені за дефіциту глюкози та глутаміну зміни у профілі експресії досліджуваних генів можуть відігравати роль у зниженні проліферації клітин гліоми з пригніченим ERN1.

Ключов і слова: експресія мРНК, TMED10, MYL9, SPOCK1, CUL4A, CUL4B, інгібування ERN1, дефіцит глюкози та глутаміну, клітини гліоми U87.

\section{References}

1. Almanza A, Carlesso A, Chintha C, Creedican S, Doultsinos D, Leuzzi B, Luís A, McCarthy N, Montibeller L, More S, Papaioannou A, Püschel F, Sassano ML, Skoko J, Agostinis P, de Belleroche J, Eriksson LA, Fulda S, Gorman AM, Healy S, Kozlov A, Muñoz-Pinedo C, Rehm M, Chevet E, Samali A. Endoplasmic reticulum stress signalling - from basic mechanisms to clinical applications. FEBS J. 2019; 286(2): 241278.

2. Lhomond S, Avril T, Dejeans N, Voutetakis K, Doultsinos D, McMahon M, Pineau R, Obacz J, Papadodima O, Jouan F, Bourien H, Logotheti M, Jégou G, Pallares-Lupon N, Schmit K, Le Reste PJ, Etcheverry A, Mosser J, Barroso K, Vauléon E, Maurel M, Samali A, Patterson JB, Pluquet O, Hetz C, Quillien V, Chatziioannou A, Chevet E. Dual IRE1 RNase functions dictate glioblastoma development. EMBO Mol Med. 2018; 10(3): e7929.

3. Papaioannou A, Chevet E. Driving cancer tumorigenesis and metastasis through UPR signaling. Curr Top Microbiol Immunol. 2018; 414: 159-192.

4. Parzych K, Saavedra-García P, Valbuena GN, Al-Sadah HA, Robinson ME, Penfold L,
Kuzeva DM, Ruiz-Tellez A, Loaiza S, Holzmann V, Caputo V, Johnson DC, Kaiser MF, Karadimitris A, Lam EW, Chevet E, Feldhahn N, Keun HC, Auner HW. The coordinated action of $\mathrm{VCP} / \mathrm{p} 97$ and GCN2 regulates cancer cell metabolism and proteostasis during nutrient limitation. Oncogene. 2019; 38(17): 3216-3231.

5. Lincet $\mathrm{H}$, Icard P. How do glycolytic enzymes favour cancer cell proliferation by nonmetabolic functions? Oncogene. 2015; 34(29): 3751-3759.

6. Dejeans N, Barroso K, Fernandez-Zapico ME, Samali A, Chevet E. Novel roles of the unfolded protein response in the control of tumor development and aggressiveness. Semin Cancer Biol. 2015; 33: 67-73.

7. AufG, Jabouille A, Guérit S, Pineau R, Delugin M, Bouchecareilh M, Magnin N, Favereaux A, Maitre M, Gaiser T, von Deimling A, Czabanka M, Vajkoczy P, Chevet E, Bikfalvi A, Moenner M. Inositol-requiring enzyme lalpha is a key regulator of angiogenesis and invasion in malignant glioma. Proc Natl Acad Sci USA. 2010; 107(35): 15553-15558.

8. Auf G, Jabouille A, Delugin M, Guérit $\mathrm{S}$, Pineau R, North S, Platonova N, Maitre M, Favereaux A, Vajkoczy P, Seno M, Bikfalvi A, Minchenko D, Minchenko O, Moenner M. High epiregulin expression in human U87 glioma cells relies on IRE1 $\alpha$ and promotes autocrine growth through EGF receptor. BMC Cancer. 2013; 13: 597.

9. Obacz J, Avril T, Le Reste PJ, Urra H, Quillien V, Hetz C, Chevet E. Endoplasmic reticulum proteostasis in glioblastoma-from molecular mechanisms to therapeutic perspectives. Sci Signal. 2017; 10(470): eaal2323.

10. Drogat B, Auguste P, Nguyen DT, Bouchecareilh M, Pineau R, Nalbantoglu J, Kaufman RJ, Chevet E, Bikfalvi A, Moenner M. IRE1 signaling is essential for ischemia-induced vascular endothelial growth factor-A expression and contributes to angiogenesis and tumor growth in vivo. Cancer Res. 2007; 67(14): 67006707.

11. Logue SE, McGrath EP, Cleary P, Greene S, Katarzyna Mnich K, Almanza A, Chevet E, Dwyer RM, Oommen A, Legembre P, Godey F, Madden EC, Leuzzi B, Obacz J, Zeng Q, Patterson JB, Jäger R, Gorman AM, Samali A. Inhibition of IRE1 RNase activity modulates the tumor cell secretome and enhances response to chemotherapy. Nat Commun. 2018; 9(1): 3267. 
12. Colombo SL, Palacios-Callender M, Frakich N, Carcamo S, Kovacs I, Tudzarova S, Moncada S. Molecular basis for the differential use of glucose and glutamine in cell proliferation as revealed by synchronized HeLa cells. Proc Natl Acad Sci USA. 2011; 108(52): 21069-21074.

13. Yalcin A, Clem BF, Imbert-Fernandez $\mathrm{Y}$, Ozcan SC, Peker S, O'Neal J, Klarer AC, Clem AL, Telang S, Chesney J. 6-Phosphofructo2-kinase (PFKFB3) promotes cell cycle progression and suppresses apoptosis via Cdk1mediated phosphorylation of p27. Cell Death Dis. 2014; 5(7): e1337.

14. Zhao S, Cai J, Li J, Guiqiu Bao G, Li D, Li Y, Zhai X, Jiang C, Fan L. Bioinformatic profiling Identifies a glucose-related risk signature for the malignancy of glioma and the survival of patients. Mol Neurobiol. 2017; 54(10): 82038210.

15. Huber AL, Lebeau J, Guillaumot P, Pétrilli V, Malek M, Chilloux J, Fauvet F, Payen L, Kfoury A, Renno T, Chevet E, Manié SN. p58(IPK)-mediated attenuation of the proapoptotic PERK-CHOP pathway allows malignant progression upon low glucose. $\mathrm{Mol}$ Cell. 2013; 49(6): 1049-1059.

16. Tsymbal DO, Minchenko DO, Riabovol OO, Ratushna OO, Minchenko OH. IRE1 knockdown modifies glucose and glutamine deprivation effects on the expression of proliferation related genes in U87 glioma cells. Biotechnol Acta. 2016; 9(1): 26-37.

17. Iurlaro $R$, Püschel $F$, León-Annicchiarico $C L$, O'Connor H, Martin SJ, Palou-Gramón D, Lucendo E, Muñoz-Pinedo C. Glucose deprivation induces ATF4-mediated apoptosis through TRAIL death receptors. Mol Cell Biol. 2017; 37(10): e00479-e00416.

18. Teramoto K, Katoh H. The cystine/glutamate antiporter $\mathrm{xCT}$ is a key regulator of EphA2 S897 phosphorylation under glucose-limited conditions. Cell Signal. 2019;62:109329.

19. Saran S, Tran DDH, Ewald F, Koch A, Hoffmann A, Koch M, Nashan B, Tamura T. Depletion of three combined THOC5 mRNA export protein target genes synergistically induces human hepatocellular carcinoma cell death. Oncogene. 2016; 35(29): 3872-3879.

20. Xu X, Gao H, Qin J, He L, Liu W. TMP21 modulates cell growth in papillary thyroid cancer cells by inducing autophagy through activation of the AMPK/mTOR pathway. Int $J$ Clin Exp Pathol. 2015; 8(9): 10824-10831.

21. Kruthika BS, Sugur H, Nandaki K, Arimappamagan A, Paturu K, Santosh V. Expression pattern and prognostic significance of myosin light chain 9 (MYL9): a novel biomarker in glioblastoma. J Clin Pathol. 2019; 72(10): 677-681.

22. Wang JH, Zhang L,Huang ST, Xu J, Zhou Y, Yu XJ, Luo RZ, Wen ZS, Jia WH, Zheng M. Expression and prognostic significance of MYL9 in esophageal squamous cell carcinoma. PLoS One. 2017; 12(4): e0175280.

23. Huang YQ, Han ZD, Liang YX, Lin ZY, Ling XH, Fu X, Cai C, Bi XC, Dai QS, Chen JH, He HC, Chen YR, Jiang FN, Zhong WD. Decreased expression of myosin light chain MYL9 in stroma predicts malignant progression and poor biochemical recurrence-free survival in prostate cancer. Med Oncol. 2014; 31(1): 820.

24. Koshizuka K, Hanazawa T, Kikkawa N, Katada K, Okato A, Arai T, Idichi T, Osako Y, Okamoto Y, Seki N. Antitumor miR-150-5p and miR-150-3p inhibit cancer cell aggressiveness by targeting SPOCK1 in head and neck squamous cell carcinoma. Auris Nasus Larynx. 2018; 45(4): 854-865.

25. Wang $T$, Liu $X$, Tian Q, Liang $T$, Chang $P$. Reduced SPOCK1 expression inhibits non-small cell lung cancer cell proliferation and migration through Wnt/ $\beta$-catenin signaling. Eur Rev Med Pharmacol Sci. 2018; 22(3): 637-644.

26. Chen D, Zhou H, Liu G, Zhao Y, Cao G, Liu Q. SPOCK1 promotes the invasion and metastasis of gastric cancer through Slug-induced epithelialmesenchymal transition. J Cell Mol Med. 2018; 22(2): 797-807.

27. Jia L, Yan F, Cao W, Chen Z, Zheng H, Li H, Pan Y, Narula N, Ren X, Li H, Zhou P. Dysregulation of CUL4A and CUL4B ubiquitin ligases in lung cancer. J Biol Chem. 2017; 292(7): 2966-2978.

28. Han X, Fang Z, Wang H, Jiao R, Zhou J, Fang N. CUL4A functions as an oncogene in ovarian cancer and is directly regulated by miR- 494 . Biochem Biophys Res Commun. 2016; 480(4): 675-681.

29. Zhou Z, Song X, Wavelet CM, Wan Y. Cullin 4-DCAF Proteins in Tumorigenesis. Adv Exp Med Biol. 2020; 1217: 241-259.

30. Zhang H, Wang X, Hu B, Zhang F, Wei H, Li L. Circular RNA ZFR accelerates non-small cell 
lung cancer progression by acting as a miR-101$3 p$ sponge to enhance CUL4B expression. Artif Cells Nanomed Biotechnol. 2019; 47(1): 34103416.

31. Li Y, Wang X. The role of cullin4B in human cancers. Exp Hematol Oncol. 2017; 6: 17.

32. Dong J, Wang XQ, Yao JJ, Li G, Li XG. Decreased CUL4B expression inhibits malignant proliferation of glioma in vitro and in vivo. Eur Rev Med Pharmacol Sci. 2015; 19(6): 1013-1021.

33. Zhao M, Qi M, Li X, Hu J, Zhang J, Jiao M, Bai X, Peng X, Han B. CUL4B/miR-33b/CMYC axis promotes prostate cancer progression. Prostate. 2019;79(5):480-488.

34. Yadav RK, Chae SW, Kim HR, Chae HJ. Endoplasmic reticulum stress and cancer. $J$ Cancer Prev. 2014; 19(2): 75-88.

35. Chevet E, Hetz C, Samali A. Endoplasmic reticulum stress-activated cell reprogramming in oncogenesis. Cancer Discov. 2015; 5(6): 586597.

36. Minchenko OH, Tsymbal DO, Moenner M, Minchenko DO, Kovalevska OV, Lypova NM. Inhibition of the endoribonuclease of ERN1 signaling enzyme affects the expression of proliferation-related genes in U87 glioma cells. Endoplasm Reticul Stress Dis. 2015; 2(1): 18-29.

37. Minchenko DO, Kharkova AP, Tsymbal DO, Karbovskyi LL, Minchenko OH. IRE1 inhibition affects the expression of insulin-like growth factor binding protein genes and modifies its sensitivity to glucose deprivation in U87 glioma cells. Endocr Regul. 2015; 49(4): 185-197.

38. Minchenko OH, Kharkova AP, Hnatiuk OS, Luzina OY, Kryvdiuk IV, Kuznetsova AY. ERN1 modifies the effect of glutamine deprivation on tumor growth related factors expression in U87 glioma cells. Ukr Biochem J. 2018; 90(3): 49-61.

39. Riabovol OO, Tsymbal DO, Minchenko DO, Lebid-Biletska KM, Sliusar MY, Rudnytska OV, Minchenko OH. Effect of glucose deprivation on the expression of genes encoding glucocorticoid receptor and some related factors in ERN1knockdown U87 glioma cells. Endocr Regul. 2019; 53(4): 237-249.

40. Halkin OV, Minchenko DO, Riabovol OO, Telychko VV, Ratushna OO, Minchenko OH. Expression of ubiquitin specific peptidase and ATG7 genes in U87 glioma cells upon glutamine deprivation. Ukr Biochem J. 2017; 89(5): 52-61.

41. Minchenko DO, Tsymbal DO, Riabovol OO, Viletska YM, Lahanovska YO, Sliusar MY, Bezrodnyi BH, Minchenko OH. Hypoxic regulation of EDN1, EDNRA, EDNRB, and ECE1 gene expressions in ERN1 knockdown U87 glioma cells. Endocr Regul. 2019; 53(4): 250-262.

42. Bochkov VN, Philippova M, Oskolkova O, Kadl A, Furnkranz A, Karabeg E, Afonyushkin T, Gruber F, Breus J, Minchenko A, Mechtcheriakova D, Hohensinner P, Rychli K, Wojta J, Resink T, Erne P, Binder BR, LeitingerN. Oxidized phospholipids stimulate angiogenesis via autocrine mechanisms, implicating a novel role for lipid oxidation in the evolution of atherosclerotic lesions. Circ Res. 2006; 99(8): 900-908.

43. Minchenko OH, Tsymbal DO, Minchenko DO, Kubaychuk OO. Hypoxic regulation of MYBL1, MEST, TCF3, TCF8, GTF2B, GTF2F2 and SNAI2 genes expression in U87 glioma cells upon IRE1 inhibition. Ukr Biochem J. 2016; 88(6): 52-62. 